INTERNATIONAL JOURNAL OF RESEARCHES IN BIOSCIENCES, AGRICULTURE AND TECHNOLOGY (c) VISHWASHANTI MULTIPURPOSE SOCIETY (Global Peace Multipurpose Society) R. No. MH-659/13(N) www.vmsindia.org

\title{
ROLE OF FUNGI IN SACRED GROVES
}

\author{
Swarupa Chaoudhuri ${ }^{1}$, Minakshi Mahajan² and Rajendra Patil ${ }^{3}$ \\ ${ }^{1,2}$ Fergusson College, Pune \\ ${ }^{3}$ Amolakchand Mahavidyalaya, Yawatmal
}

\section{Abstract}

Sacred groves are the places responsible for conservation of biodive rsity. These areas are not destructed areas. We have visite d a sacred grove at Taminhi. Observed some fungi in the sacred groves.Fungi have the ir role in cycling of nutrients in the sacred groves.

Ke ywords- fungi, sancred groves, vinzai de vrai

\section{Introduction}

Sacred groves are preserved patches of forest areas. Sacred groves are the places of natural vegetation reserved under the name of gods. Such sacred groves were preserved in ancient Asisa, Africa, Europe, America and Austrpacific region (Hughes and Chandran, 1998). They are found in the past as well as in the present among people with many religions.

An International Organisation UNESCO is taking lot of inte re st in sacred sites for making funds available throughout the world. (Hay-Edie and Hadley, 1988). Sacred groves reserved several hundred hectares areas. The largest sacred grove was the Halesorabakan having an area about 400 ha (Brandis nd Grant, 1868).

Sacred groves are repositories of rare, endangered, species. In comparis on to adjoining landscape e le ments (Bhakat, (2004), Bhagwat \& et.al. (2005), Khan et. al., (2008). Sacred groves particularly deal with the study of species composition, dominance, distribution rare, endemic, conservation, microflora and fauna. (Vartak and Ku mbhojkar, (1984), Puspanghad an et. al. (1996), Upadhaya et. al. (2003), Kumbongmayum et. al., (2005).

The role of sacred groves is in conserving the flora and fauna. Various type of vegetation is recorded in sacred groves. Sacred groves of Eastern ghat is of dry evergreen fores t vege tation. The growing plants are with two-laye red canopy. The dominant plants of groves beloniging to the families like Fabaceae, Moraceae, Capparidaceae, Ebenaceae, Rubiaceae and Rutaceae. (Parthasarthy, (1997), Sukumaram, (2005, 2007).

Eastern Ghat groves have dry evergreen forest vegetation with characteristic two-layered canopy, dominated by members of Fabaceae, Moraceae, Capparaceae, Ebe naceae, Rubiaceae and Rutaceae (Parthasarathy, 1997; Sukumaran, 2005, 2007).

Sacred groves dealt with the lower micro and macro flora and fauna. The availale light conditions at ground level due to canopy gaps created by tree falls facilitate rapid growth of seedlings and provide suitable microenvironme nt for rapid growth of lower plants on ground level. (Khumbongmayum et al. 2005, Laloo et al 2006).

\section{Material and Methods}

We have visited two sacred groves namely Vinzai devrai and Shankar devrai at Taminhi, Mulshi taluka, Pune on 2/7/2017 Obse rved some fungi. Photographs we re taken.

\section{Result and Discussion}

Following fungi are found at vinzai devrai, Tamini Fungi- Fungi play vital roles in the biosphere. They are essential to the recycling of nutrie nts in all terrestrial habitats because they are the dominant decomposers of the complex components of plant debris, such as cellulose and lignin. Fungi are unicellular or multicellular eukaryotic organisms. They play an important role in cycling of nutrie nts due to the ir ability to decompose organic matter. Ecologists consider decomposition of organic matter is the majr ecological role of fungi. In the sacred groves many organisms depend on fungi for survival. Wood fungi have their gre at role in breaking down lignin content of wood by their enzymes. Therefore they are referred as wood decomposers. Uncommon fungi like cordyceps entomogenic fungi and Clathrus basket fungi observed.

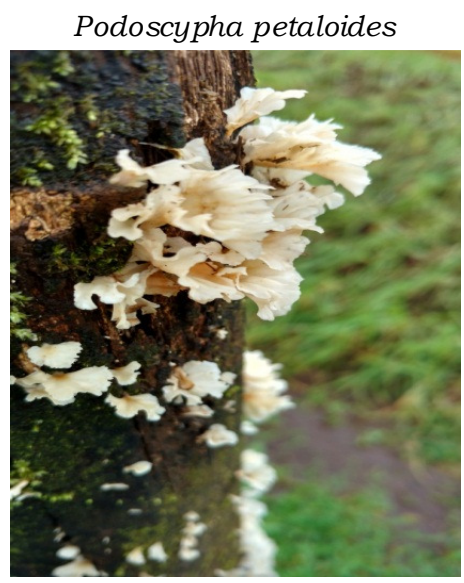




\section{Dacryopinax spathularia/ tremella}

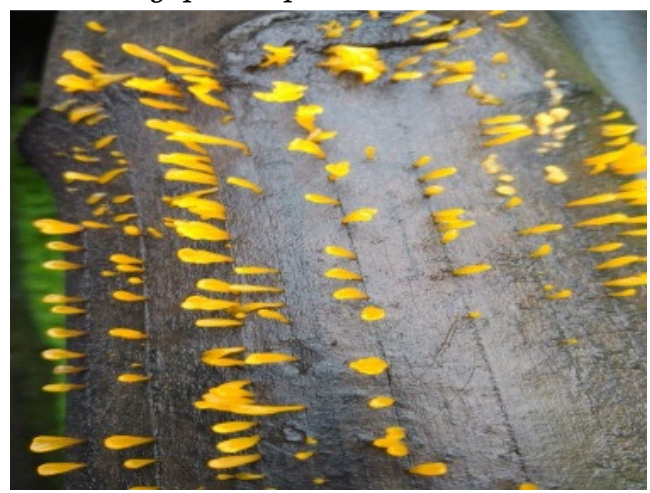

Elatrus foot balls net like forms Marasmius

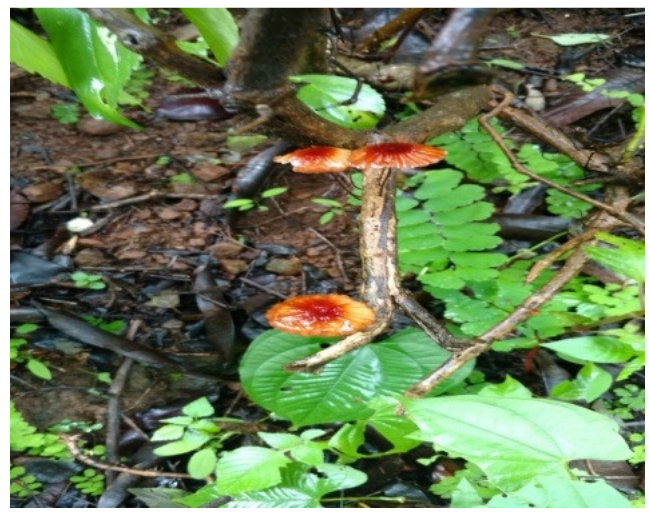

Xylaria

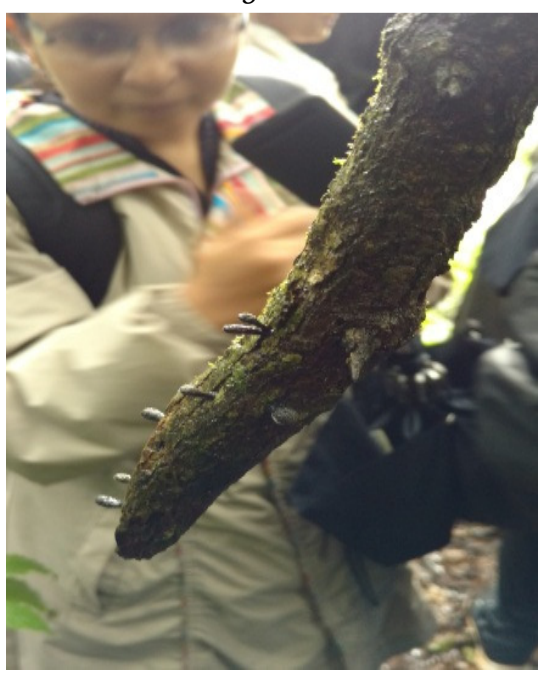

Cordyceps- • Fungi-Insect Association

This fungus is entomogenous fungi. They have symbiotic relationship with them. Insects like ants, termites and bee tles cultivate fungi for food purpose. Some insects use fungi for depositing their eggs. Developing larvae derive nutrition from fungi.

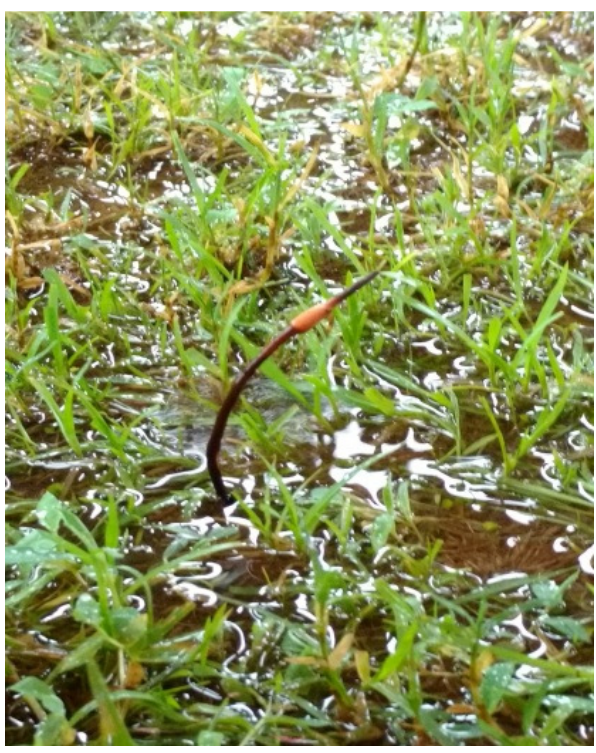

Wood rotting fungi- Ganoderma

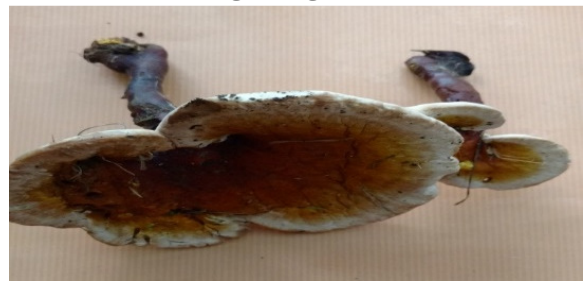

Agaricus

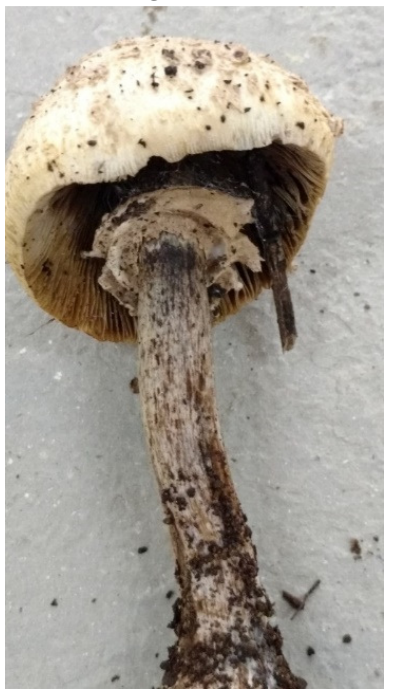

Panaeolus 


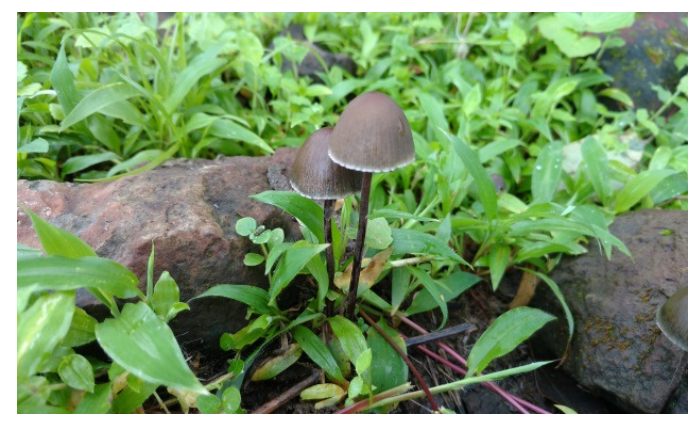

Acknowledgement-

Authors are thankful to Dr. Sachin Punekar, Founder President of Biospheres: Pune based NGO.

\section{References-}

Bhagwat S, Kushalappa CG, Williams PH, Brown NC. 2005. A Landscape Approach to Biodive rsity Conservation of Sacred Groves in the Western Ghats of India. Conservation Biology, 19:18531862.

Bhagwat, S.A., C.G. Kushalappa, P.H. Williams and N.D. Brown. 2005b.The role of informal protected areas in maintaining biodiver-sity in the Western Ghats of India. Ecology and Society $10(1): 8$

Bhakat RK, Pandit PK. 2004. An inventory of medicinal plants of some sacred groves of Purulia district, We st Bengal. Indian Forester, 130: 37 44.

Brand is, D. and Grant, 1868. Joint report no.33, dated 11 th May, on the kans in the Sorab taluka, Forest Department, Shimoga.

Hay-Edie, T. and Hadley, M. 1998. -see PS Ramakrishnan et.al Ed.

Hughes JD, Chand ran MDS. 1998. Sacred groves around the Earth: An overview. In: Ramakrishnan PS, Chandrashekhara UM, Saxena KG (eds), Conserving the sacred for biodiversity manage ment. New Delhi, Kolkata: Oxford \& IBH Publishing Co. Pvt. Ltd., pp. 69-86.
Hughes, J.D. and Chandran, M.D.S. 1998 - see PS Ramakrishnan, et al Ed.

Hughes,D.J. and Chandran, S.MD. 1998Sacred grove around the earth An Overview. Pages 69-86 In Rama-krishnan,P.S.Saxena KG.a nd Chand rashekara, U.M.(Editors)Conserving the Sacred for BiodiversityManagement UNESCOanxford-IBH Publing,New Delhi

Khan ML, Khumbongmayum AD, Tripathi RS. 2008. Sacred groves and their significance in conserving biodiversity: An overview. International Journal of Ecology and Environment Scie nce, 34: 277-291.

Khumbongmayum AD, Khan ML, Tripathi RS. 2005. Ethno medicinal plants in the sacred groves of Manipur. Indian Journal of Traditional Knowled ge, 4: 21-32.

Laloo RC, Kharlukhi L, Jeeva S, Mishra BP. 2006. Status of medicinal plants in the disturbed and the undisturbed sacred forests of Meghalaya, northeast India: population structure and regene ration efficacy of some important species. Current Science, 90: 225-232.

Parthasarathy N, Karthikeyan R. 1997. Plant biodiversity inventory and conservation of two tropical dry evergreen forests on the Coromandel coast, south India. Biodiversity and Conservation, 6: 1063-1083.

Pushpangad an P, Raje ndraprasad M, Krishnan PN. 1998. Sacred groves of Kerala - A synthesis on the state of-art-of knowledge. In: Ramakrishnan PS, Chand rashekhara UM, Saxena KG (eds.), Conserving the sacred for biodiversity management. New Delhi, Kolkata: Oxford \& IBH Publishing Co. Pvt. Ltd., pp. 193209.

Upadhaya K, Pandey HN, Law PS, Tripathi RS. 2003. Tree diversity in sacred groves of the Jaintia hills in Meghalaya, northeast India. Biodiversity and Conse rvation, 12: 583-597.

Vartak VD, Kumbhojkar MS. 1984. Notes on the lianas of some sacred groves in Western Maharashtra. Biovigyanam 11:214-215. 